\title{
BACTERIAL FLORA PLAY IMPORTANT ROLES IN ACUTE DEXTRAN SULPHATE SODIUM-INDUCED COLITIS BUT ARE NOT INVOLVED IN GAL-3 DEPENDENT MODULATION OF COLON INFLAMMATION
}

Bojana Simovic Markovic ${ }^{1}$, Neda Milosavljevic ${ }^{1}$, Aleksandar Arsenijevic ${ }^{1}$, Marina Gazdic ${ }^{1}$, Miodrag L. Lukic ${ }^{1}$ and Vladislav Volarevic ${ }^{1 *}$

${ }^{1}$ Center for Molecular Medicine and Stem Cell Research, Faculty of Medical Sciences, University of Kragujevac, Kragujevac, Serbia

\author{
BAKTERIJSKA FLORA IGRA VAŽNU ULOGU U AKUTNOM KOLITISU \\ IZAZVANOM DEKSTRAN NATRIJUM SULFATOM, ALI NIJE POVEZANA \\ SA GAL-3 ZAVISNOM MODULACIJOM INFLAMACIJE U KOLONU \\ Bojana Simović Marković ${ }^{1}$, Neda Milosavljević ${ }^{1}$, Aleksandar Arsenijević ${ }^{1}$, Marina Gazdić ${ }^{1}$, Miodrag L. Lukić ${ }^{1}$ and Vladislav Volarević ${ }^{1}$ \\ ${ }^{1}$ Centar za molekulsku medicinu i istraživanje matičnih ćelija, Fakultet medicinskih nauka, Univerzitet u Kragujevcu, Kragujevac, Srbija
}

\begin{abstract}
An altered immune response to normal gut microflora is important for the pathogenesis of ulcerative colitis (UC). Galectin-3 (Gal-3) is an endogenous lectin that plays an important pro-inflammatory role in the induction phase of acute colitis by promoting activation of the NLRP3 inflammasome and production of IL-1 $\beta$ in macrophages. By using dextran sulphate sodium (DSS) induced colitis, a well-established animal model of UC, we determined whether Gal-3 affects the function of colon infiltrating macrophages by interfering with intestinal microflora.

Our results showed that genetic deletion of Gal-3 significantly attenuates DSS-induced colitis by down-regulating infiltration of phagocytic cells (neutrophils, macrophages and dendritic cells) in colon tissue of DSS-treated mice, and this correlated with differences in bacterial flora of the gut. Antibiotic treatment attenuates DSS-induced colitis in WT and Gal-3-mice without affecting differences between the groups.

In conclusion, Gram negative bacterial flora play an important role in DSS-induced acute colitis of mice but are not involved in Gal-3 dependent modulation of colon inflammation.
\end{abstract}

Keywords: acute DSS-induced colitis, microflora, Gal-3

\section{SAŽETAK}

Promenjen imunski odgovor na komensalne bakterije u gastrointestinalnom traktu je važan za patogenezu ulceroznog kolitisa. Galektin-3 (engl. Galectin-3, Gal-3) je endogeni lektin, koji igra važnu proinflamacijsku ulogu u inicijalnoj fazi akutnog kolitisa, tako što promoviše aktivaciju NLRP3 inflamazoma i produkciju IL-1ß u makrofagima.

U ovom istraživanju ispitivan je uticaj Gal-3 na mikrofloru u patogenezi akutnog kolitisa izazvanog dekstran natrijum sulfatom (engl. Dextran sulphate sodium, DSS).

Delecija gena za Gal-3 je znacajno smanjila oštećenje tkiva kolona životinja tretiranih DSS-om. U poređenju sa WT mišsvima, u tkivu kolona DSS-tretiranih Gal-3- zivotinja je bila značajno manja zastupljenost fagocita (neutrofila, makrofaga i dendritskih ćelija) sto je koreliralo sa promenama u sastavu bakterijske crevne flore. Primenom antibiotika ublazio se razvoj akutnog kolitisa, ali bez uticaja na već postojeću razliku u bolesti između WT $i$ Gal-3- miševa.

Gram negativna bakterijska flora igra važnu ulogu u akutnom kolitisu izazvanom DSS-oм, ali ne učestvuje u Gal3 zavisnoj modulaciji inflamacije kolona.

Ključne reči: akutni kolitis, mikroflora, Gal-3, DSS

\section{INTRODUCTION}

Ulcerative colitis (UC) is a chronic inflammatory disorder of the gastrointestinal tract (1). The etiology of UC is still elusive, and many factors have been reported to be involved in the development of this disease, including epithelial cell destruction, genetic susceptibility and modulation of bacterial flora in the intestinal environment. Therefore, murine models have become essential tools to investigate the pathophysiological mechanisms and immunological processes underlying chronic mucosal inflammation in the colon (2). Dextran sulphate sodium (DSS)-induced colitis is a fre- quently used animal model of UC (3). Intestinal microflora play an important role in the susceptibility and responsiveness to DSS-induced colitis (4). DSS induces mucosal injury and inflammation, initially through a direct toxic effect on epithelial cells, followed by invasion of intestinal bacteria into subepithelial tissue and subsequent recruitment and activation of inflammatory cells: neutrophils, macrophages, eosinophils, mast cells, dendritic cells (DCs), and NKT cells, accompanied by production of inflammatory mediators, and leading to the development of severe colitis (4). 
Galectin-3 (Gal-3) is an endogenous lectin that exerts both pro- and anti-inflammatory effects, depending on the disease condition. It plays an important disease-exacerbating role in autoimmune/inflammatory and malignant diseases (5-9) but has a protective role in obesity-induced inflammation and type 2 diabetes, as well as in primary biliary cirrhosis $(10,11)$. Recently, several clinical studies showed a correlation between the serum level of Gal-3 and exacerbation of acute colitis, indicating the importance of Gal-3 as a potential marker for this disease (12-14). Serum concentrations of Gal-3 were significantly increased in specimens from patients with the active form of UC (12). Recently, we showed that Gal-3 plays an important proinflammatory role in the induction phase of acute DSSinduced colitis by promoting activation of the NLRP3 inflammasome and production of IL-1 $\beta$ in macrophages (7).

In this study, we investigated whether Gal-3 affects the function of colon infiltrating macrophages by interfering with intestinal microflora and whether these interactions are important in the development and progression of DSSinduced colitis.

\section{MATERIALS AND METHODS}

\section{Animals}

Male, 6-8-week-old wild type (WT) and Gal-3-1C57BL/6 mice (provided by Dr Daniel Hsu, University of California, Sacramento, CA) were used for the induction of DSS-induced colitis. Targeted disruption of the mouse Gal-3 gene was performed in C57BL/6 embryonic stem cells, and mice homozygous for the disrupted gene were obtained (15). Breeding pairs of Gal-3/- and WT Gal-3 ${ }^{+/+}$ C57BL/6 mice of the same substrain were maintained in the animal facilities of the Faculty of Medical Sciences, University of Kragujevac, Serbia. All animals received humane care, and all experiments were approved by and conducted in accordance with the Guidelines of the Animal Ethics Committee of the Faculty of Medical Sciences, University of Kragujevac, Serbia. Mice were housed in a temperaturecontrolled environment with a 12-h light-dark cycle and were administered standard laboratory chow and water ad libitum.

\section{Induction of acute colitis}

Colitis was induced with $3 \% \mathrm{w} / \mathrm{v}$ DSS (molecular weight $40 \mathrm{kDa}$; TdB Consultancy, Uppsala, Sweden) dissolved in drinking water given ad libitum for up to 7 days, as previously described (3). Control mice were given DSS-free water.

\section{Assessment of the severity of colitis}

The Disease Activity Index (DAI) was used to assess clinical signs of colitis (16). Body weight measurements, analysis of stool consistency, and faecal occult blood tests were performed daily. Body weight was measured daily and compared with the body weight measured on day 0 (the 1 st day of DSS administration). The results are presented as $\pm \%$ body weight loss.

\section{Histology}

For histological analysis, colons were removed from euthanised mice, rinsed with phosphate buffer solution (PBS), and cut longitudinally before being rolled into a 'Swiss roll', as previously described (17). Swiss rolled colons were fixed in formalin and embedded in paraffin, and $5-\mu \mathrm{m}$ sections were stained with haematoxylin-eosin (H\&E) and examined in a blinded manner by a pathologist. Sections were analysed for damage to the epithelium including damage to crypts, submucosal oedema, haemorrhage, and infiltration by immune cells. The histology score for each mouse was calculated as the sum of 'Infiltration' and 'Damage of Epithelium' sub-scores, as previously described (18).

\section{Flow cytometry analysis of colon infiltrating cells}

Isolation of immune cells from the lamina propria and flow cytometry analysis were conducted as previously described (7). Briefly, each colon was dissected away from the caecum. The colon was cut into pieces $3 \mathrm{~cm}$ long and then cut longitudinally, so that $3 \times 3 \mathrm{~cm}$ flaps of colonic tissue were made. The flaps were placed in a $50 \mathrm{ml}$ conical tube and washed three to five times with $30 \mathrm{ml}$ cold HBSS, calcium and magnesium free. After decanting the supernatant, the pieces were incubated in $20 \mathrm{ml} \mathrm{HBSS/EDTA} \mathrm{for}$ $30 \mathrm{~min}$ in a $37^{\circ} \mathrm{C}$ water bath. Each tube was shaken regularly during the incubation to ensure that epithelial cells were disrupted from the mucosa. The pieces were sedimented, and the supernatant was decanted. The remaining EDTA was washed out with $40 \mathrm{ml} \mathrm{HBSS}$, calcium and magnesium free. The fragments of colonic tissue were placed in a 5 $\mathrm{cm}$ Petri dish and cut into smaller pieces with a scalpel. The pieces were aspirated with a pipette, transferred to a fresh $50 \mathrm{ml}$ conical tube and filled to $20 \mathrm{ml}$ with Dulbecco's Modified Eagle Medium (DMEM) supplemented with 10\% foetal bovine serum (FBS). Then, $1 \mathrm{ml}$ of 4000 Mandl units (3 x $10^{6}$ Wünsch units)/ml collagenase D and $200 \mu \mathrm{l}$ of 1 $\mathrm{mg} / \mathrm{ml} \mathrm{DNase}$ were added to the tube and incubated for $1 \mathrm{~h}$ in a $37^{\circ} \mathrm{C}$ water bath. The supernatant was filtered through a $100 \mu \mathrm{m}$ nylon cell strainer into a clean $50 \mathrm{ml}$ conical tube. Cold HBSS, calcium and magnesium free, was added to a volume of $50 \mathrm{ml}$. Cells were pelleted by centrifuging $10 \mathrm{~min}$ at $450 \mathrm{~g}$, at $4^{\circ} \mathrm{C}$. The pellet was disrupted, and cells were re-suspended in $50 \mathrm{ml} \mathrm{HBSS}$, calcium and magnesium free, and filtered through a $40-\mu \mathrm{m}$ nylon cell strainer into a clean $50 \mathrm{ml}$ conical tube. Cells were again pelleted by centrifuging $10 \mathrm{~min}$ at $450 \mathrm{~g}$, at $4^{\circ} \mathrm{C}$. The pellet was disrupted, and cells were re-suspended in $20 \mathrm{ml}$ of $30 \%$ Percoll. Then, the cell suspension was carefully layered over $25 \mathrm{ml}$ of $70 \%$ Percoll in a 50-ml conical tube and centrifuged for $20 \mathrm{~min}$ at $1100 \mathrm{x}$ g, room temperature, with as low an acceleration rate as possible and with the brake off. Clumping of cells was prevented by the addition of $1 \mathrm{mM}$ EDTA to the solution. Epithelial cells floated on the 30\% Percoll layer, and immune cells were found between the $30 \%$ and $70 \%$ layers. 


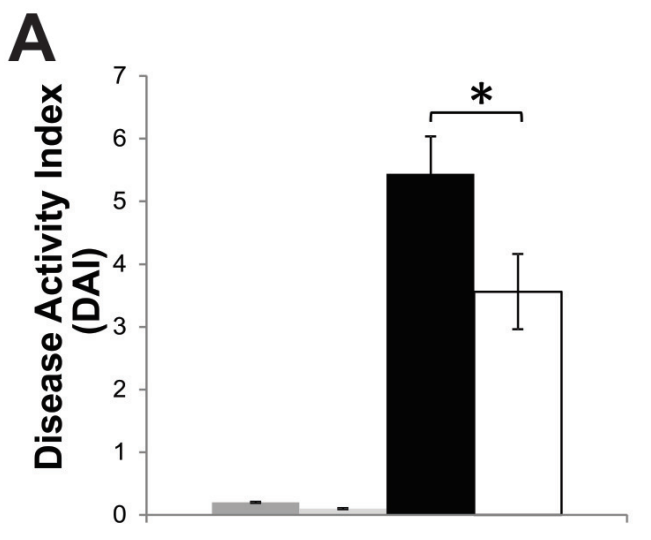

B

C

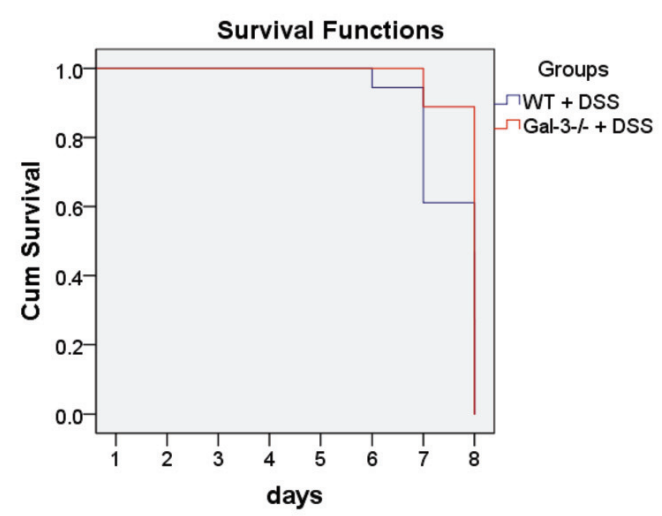

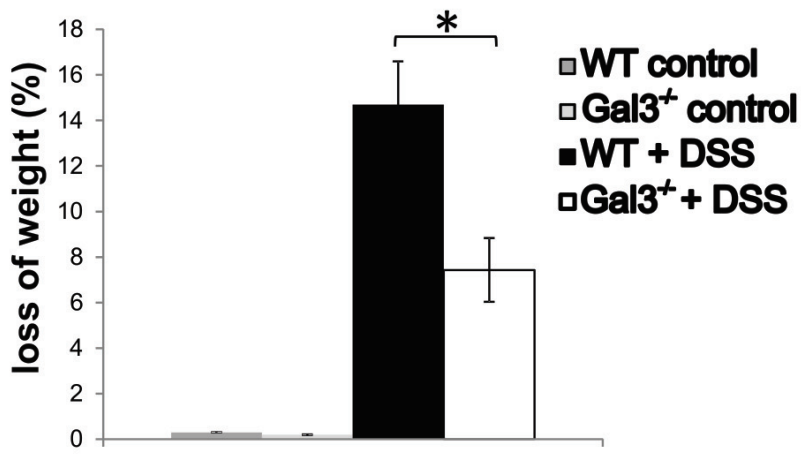

D

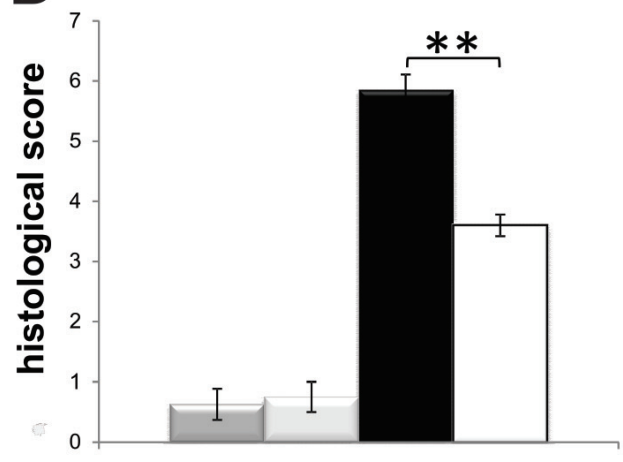

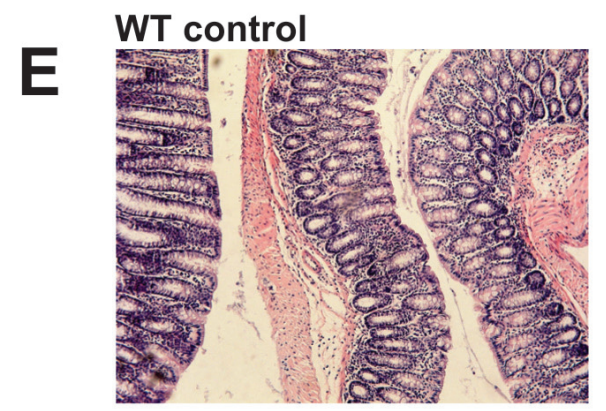

Gal-3-1- control

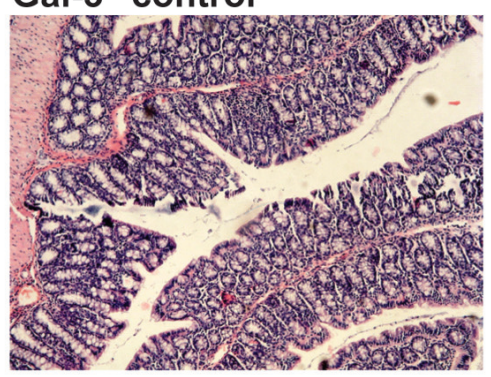

WT + DSS

Gal-3 ${ }^{-/-}$+ DSS
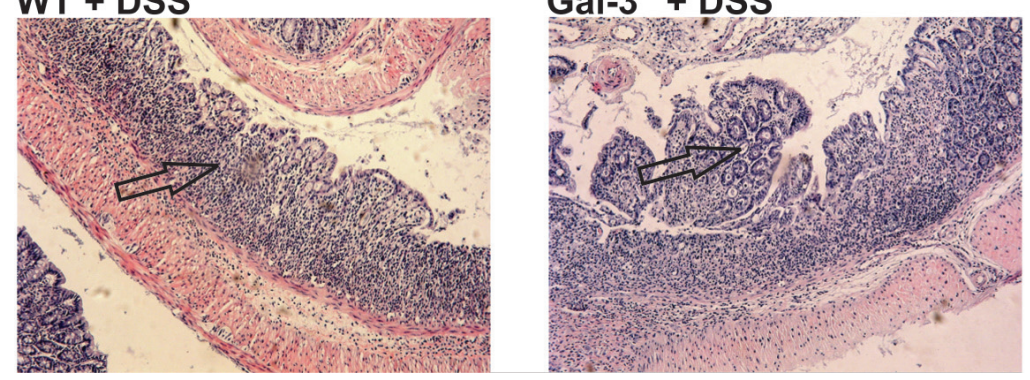

Figure 1. Galectin-3 deficiency attenuates DSS-induced colitis. Water with 3\% DSS was given to mice for 7 days; regular drinking water was fed to control mice. Disease Activity Index (DAI) was scored at day 7 using the following parameters: weight loss, stool consistency, and rectal bleeding (A, B). Survival rate of mice with colitis (C). Histological examination was performed with haematoxylin and eosin (H\&E) staining. H\&E stained images of representative colon tissues are shown at the same magnifications $(100 x)(D, E)$. Data presented as the mean \pm standard error of the mean $(\mathrm{SEM}) ; \mathrm{n}=$ 10 mice per experimental group. " $\mathrm{p}<0.05,{ }^{*}$ " $\mathrm{p}<0.001$. 


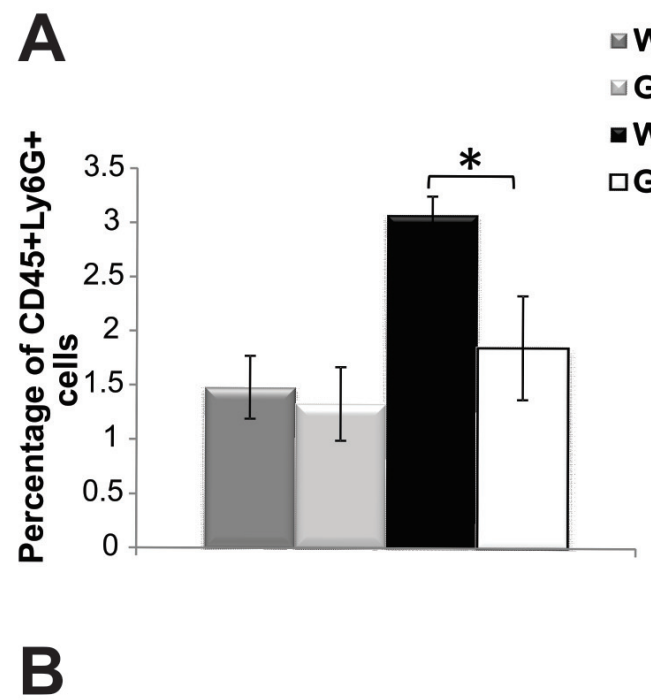
$\square$ WT control
$\triangle$ Gal-3t $^{\text {th }}$ control
- WT + DSS
$\square \mathrm{Gal}^{+{ }^{+}}+\mathrm{DSS}$
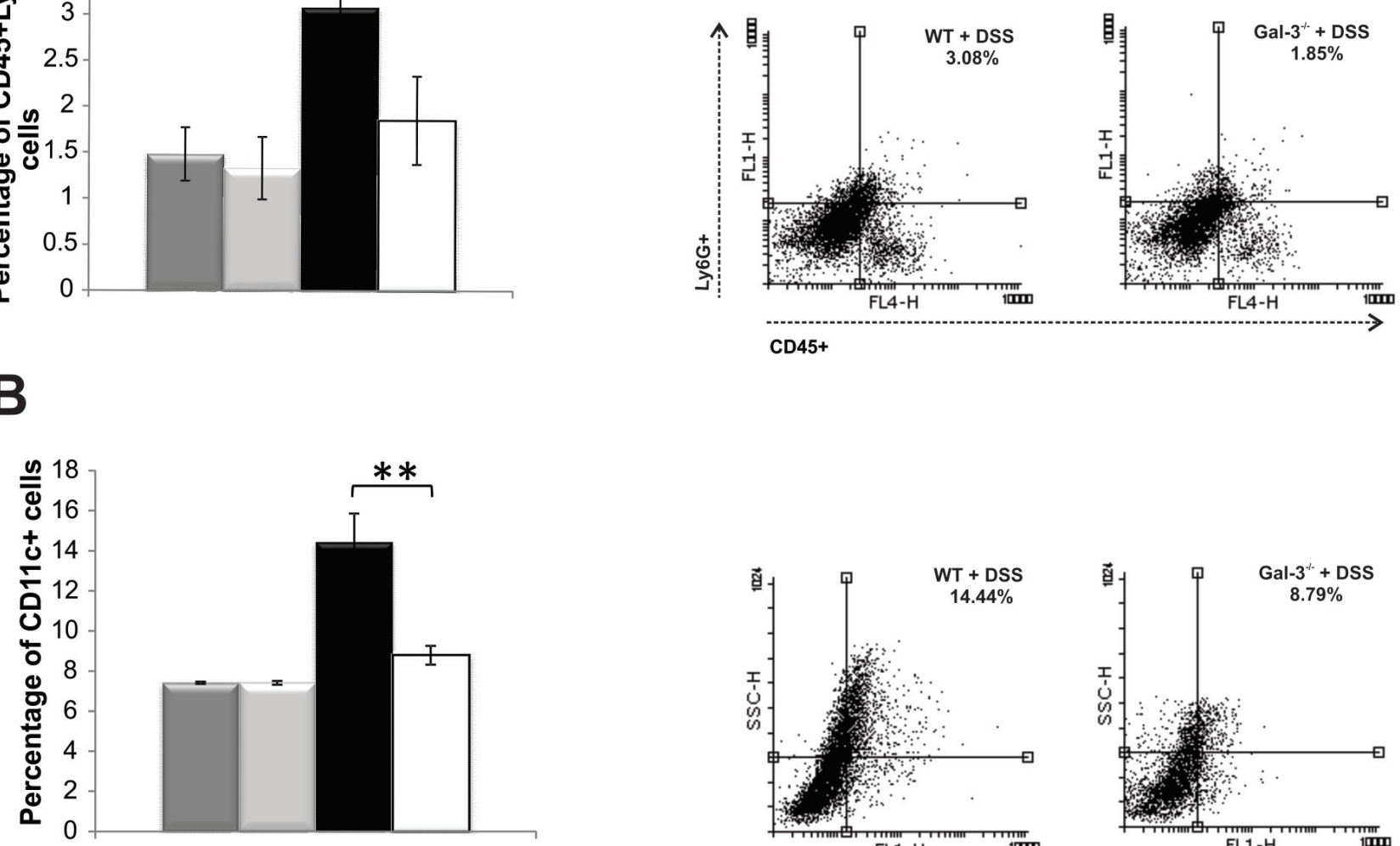

B

C
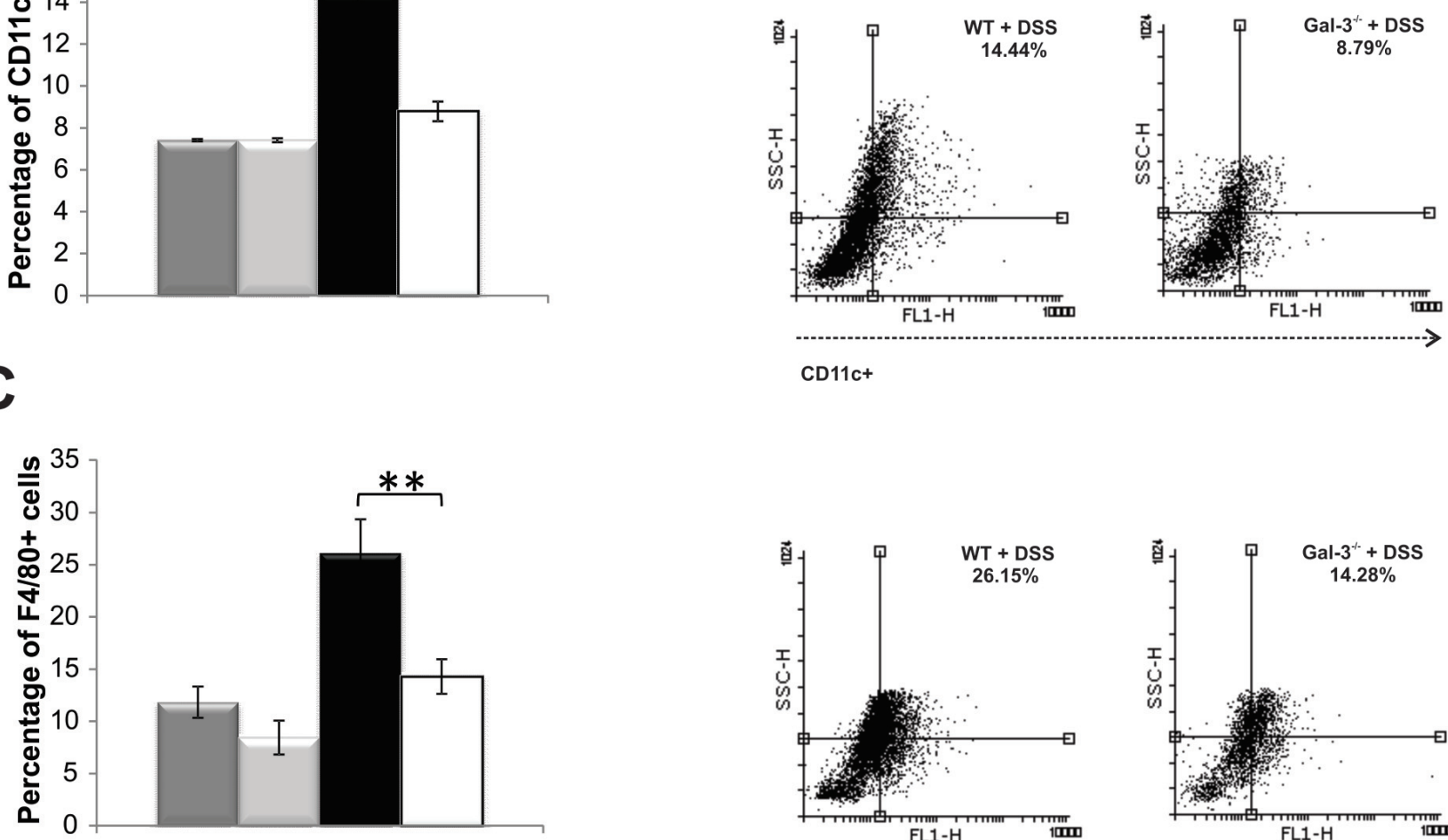

CD11c+

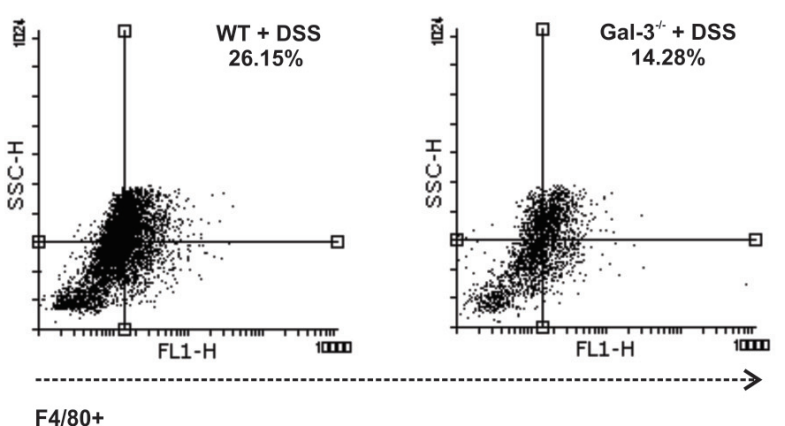

Figure 2. Genetic deletion of Gal-3 decreases the percentage of neutrophils, dendritic cells and macrophages in the colons of DSS-treated mice. The percentage of neutrophils (CD45+Ly6G+), CD11c+ dendritic cells, and F4/80+ macrophages was significantly lower in colons of DSStreated Gal- ${ }^{-/}$mice (A-C). Representative flow cytometry dot plots are shown. Values are the mean \pm standard error of the mean $(\mathrm{SEM})(\mathrm{n}=10$ per group). " $\mathrm{p}<0.05,{ }^{* *} \mathrm{p}<0.001$.

Debris and dead cells were pelleted at the bottom of the conical tube.

Flow cytometry followed routine procedures by using $1 \times 10^{6}$ cells per sampwhichle, which were incubated with anti-mouse F4/80, CD11c, CD45, and Ly6G conjugated to fluorescein isothiocyanate (FITC; BD Biosciences, Franklin Lakes, NJ), or allophycocyanin (APC; BD Biosciences).
Flow cytometric analysis was conducted on a BD Biosciences FACSCalibur and analysed using the Flowing software analysis program.

\section{Antibiotic treatment}

To investigate the potential role of the microbiota and their relationship with Gal-3 in acute DSS-induced colitis, 


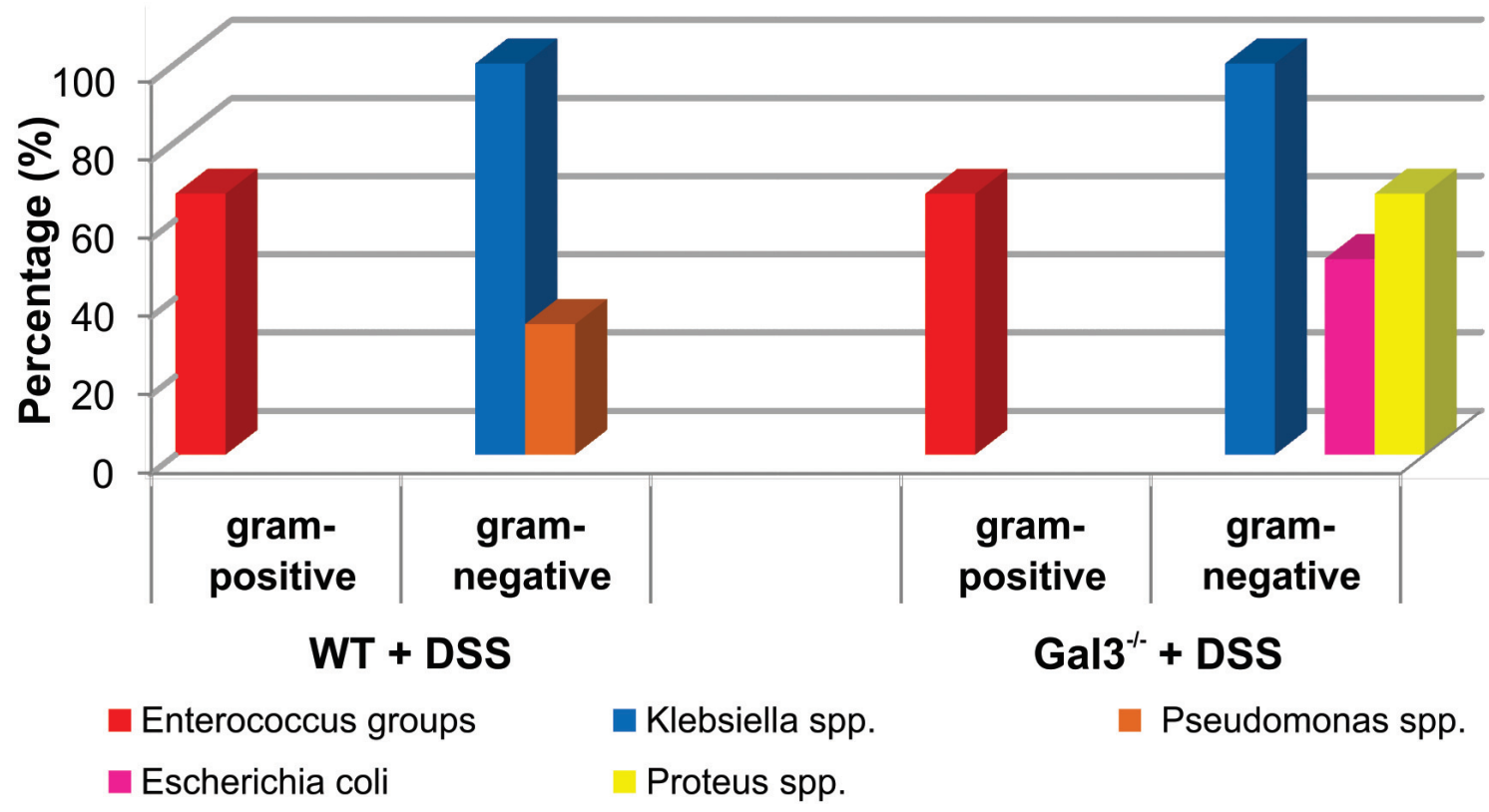

Figure 3. Bacterial strains isolated from the stools of WT and Gal-3 ${ }^{-/-}$DSS-treated mice. The graphs show the percentage of mice in whose stools different bacterial strains were isolated. Red bars represent Enterococcus groups, blue bars represent Klebsiella spp., orange bars represent Pseudomonas spp., pink bars represent Escherichia coli, and yellow bars represent Proteus spp.

experimental animals received water supplemented with antibiotics. Mice were treated daily with antibiotics (metronidazole $(1 \mathrm{mg} / \mathrm{g})$ and ciprofloxacin $(0.5 \mathrm{mg} / \mathrm{g}))$, intraperitoneally injected from day 0 to the last day of the experiment. (19). A fresh stool sample was collected in a clean tube and processed for bacteria determination. Samples were then placed in a special dish, which was filled with a gel that boosts the growth of bacteria, as previously described (20).

\section{Statistics}

Data are expressed as the mean \pm SEM for each group. We tested for normality using the Shapiro-Wilk's test and for homogeneity of variances using Levine's test. A paired samples $t$-test was used to compare the two matched groups. The independent samples Student's $t$-test was otherwise used to compare two groups with a Gaussian distribution. Fisher's exact test was used to assess survival differences between groups. Statistical analyses were performed using SPSS 21.0 for Windows (SPSS, Inc., Chicago, IL). All reported $p$ values were 2 -sided, $\mathrm{p}<0.05$ was considered statistically significant, and $\mathrm{p}<0.001$ was considered highly significant.

\section{RESULTS}

Genetic deletion of Gal-3 significantly attenuated DSS- induced colitis

Genetic deletion of Gal-3 attenuated DSS-induced colitis, according to the clinical parameters assessed (Figure $1 \mathrm{~A})$, loss of weight (Figure 1B), and the survival rate (Figure 1C). All DSS treated WT mice developed severe colitis with similar clinical symptoms: diarrhoea, rectal bleeding, and weight loss. The presence of blood in the faeces was detected one to two days after the start of DSS treatment, whereas gross bleeding and diarrhoea were observed from day 4 . Significant body weight loss $(>5 \%)$ became prominent after five days of DSS treatment. These observations were confirmed by histological analysis (Figure 1D). The DSS-treated group clearly exhibited a severe mucosal inflammatory cell infiltration and a disruption of crypt architecture (epithelial ulcerations and loss of goblet cells), whereas lesions were prevented in Gal-3 ${ }^{-/}$animals treated with DSS (Figure 1E, low panel).

Gal-3 deletion significantly reduced the presence of phagocytic cells in DSS-injured colons

Genetic deletion of Gal-3 markedly decreased the numbers of neutrophils, dendritic cells and macrophages in colon tissue. Flow cytometry analysis showed a significantly lower percentage of CD45+Ly6G+ neutrophils, CD11c+ DCs and F4/80+ macrophages in colon tissue of DSS-treated Gal-3 ${ }^{-/}$mice (Figure 2), indicating the important role that Gal-3 plays in the infiltration of phagocytic cells in DSS-injured colons.

To assess the differences in bacterial microflora between DSS-treated WT and Gal- $3^{-/}$mice, microflora of the gut were analysed. There were no differences in Gram positive bacteria, while significant differences in Gram negative bacterial flora of the gut were observed. Enterococcus and Klebsiella species were found in both DSS-treated WT and Gal-3-- mice. Pseudomonas species were found only in the DSS-treated WT mice, while Escherichia coli and Proteus species were found only in the DSS-treated Gal-3/- mice (Figure 3). 

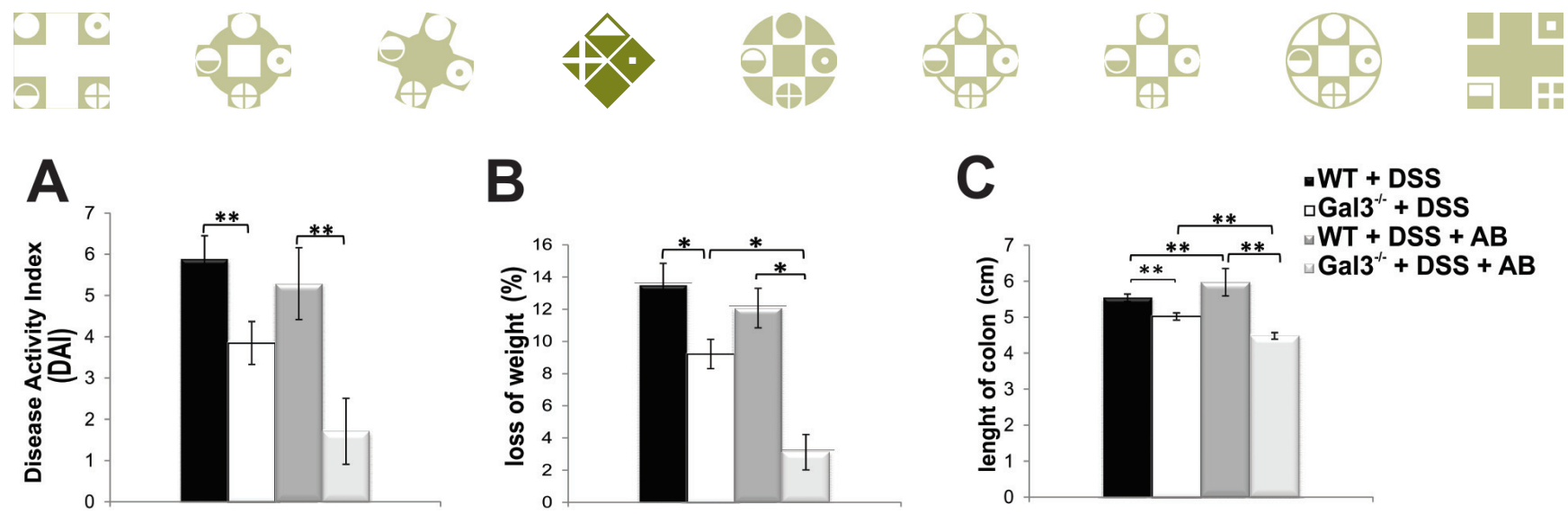

B
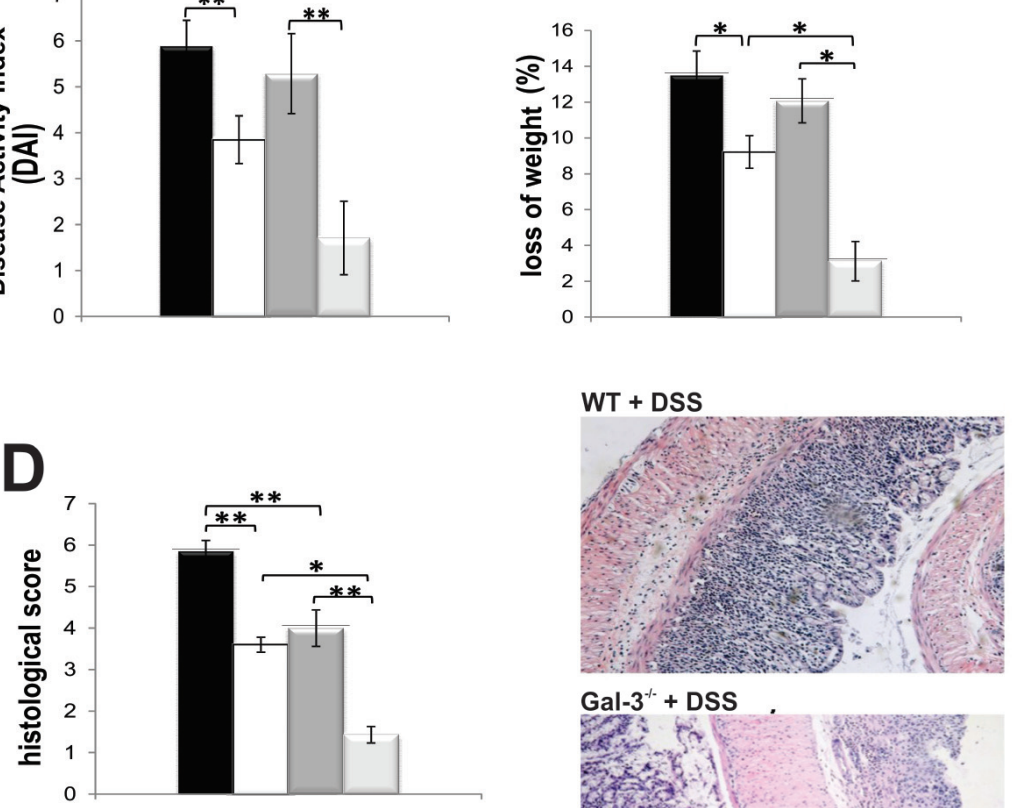

C
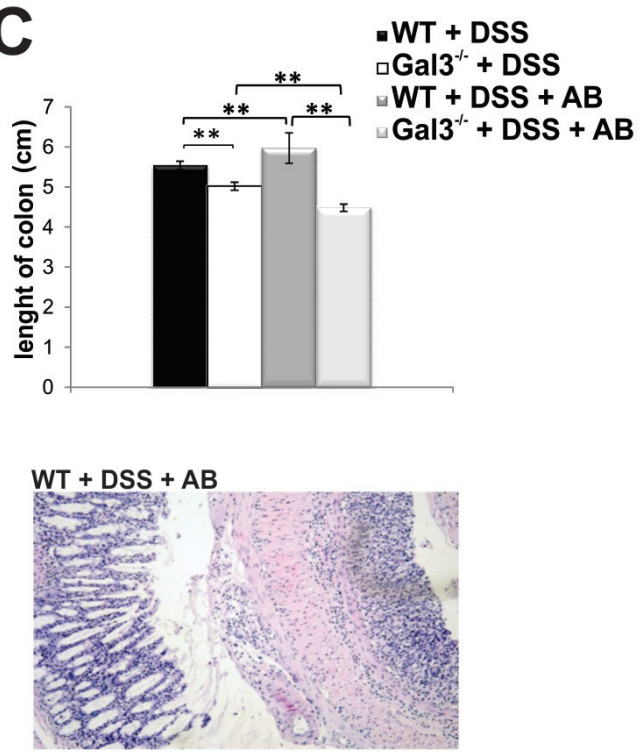

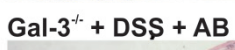

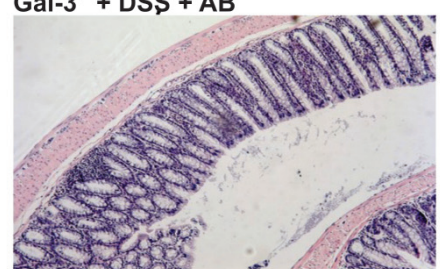

Figure 4. Antibiotic treatment ameliorated DSS-induced colitis. Antibiotics were intraperitoneally administered to DSS-treated mice. After 7 days, the DAI was evaluated, and colon length was measured (A-C). Histological score as well as representative photomicrographs $(\times 100$ magnification) of colon sections are shown (D). Values are the mean \pm standard error of the mean (SEM) ( $\mathrm{n}=10$ per group). ${ }^{*} \mathrm{p}<0.05,{ }^{* * *} \mathrm{p}<0.001$.

\section{Antibiotic treatment significantly attenuated DSS- induced colitis without affecting differences between WT and Gal-3-- mice}

The use of antibiotics, which are effective against Gram negative bacteria (19), attenuated DSS-induced colitis, ameliorated diarrhoea and rectal bleeding, and reduced the loss of body weight (Figure 4A, B). Colon shortening was significantly lower in the DSS-treated Gal-3/- mice compared to the WT DSS-treated animals (Figure 4C). These findings were confirmed by histological analysis. In DSS-treated mice that received antibiotics, the colonic mucosa showed only slight pathological changes, including a reduced extent of colon damage and reduced infiltration of inflammatory cells (Figure 4D). The structure of the crypt epithelial cells remained intact, and the histopathological injury scores were significantly decreased when compared with DSS-only treated animals (Figure 4D). Most importantly, it appears that antibiotic treatment has a protective effect in DSS-induced colitis but does not affect the differences between the DSS-treated WT and Gal- $3^{-1-}$ mice. The difference in clinical and histological parameters of DSS-induced colitis remained statistically significant between the antibiotic treated WT and Gal-3/- animals (Figure 4).

\section{DISCUSSION}

There is increasing evidence that intestinal microflora play an important role in the pathogenesis of UC. Several studies in animal models of intestinal inflammation suggest that the inflammatory responses are triggered by normally nonpathogenic microbial flora. Bacteria are of prime importance for the onset of UC in IL-2-deficient mice, which are free of symptoms when they are kept in a germfree environment (21). Additionally, IL-10-deficient mice develop an attenuated disease when they are kept in a facility with a defined microbial environment $(22,23)$. Indirect evidence for the involvement of microorganisms in these findings includes the increased infiltration of phagocytic cells into the inflamed colons, which is followed by an uptake of luminal antigens (24) and the onset of inflammation in injured colons $(24,25)$.

It is well known that Gal-3 is involved in migration of phagocytic cells $(26,27)$. Accordingly, we found a significantly lower percentage of neutrophils, DCs and macrophages in the DSS-injured colons of $\mathrm{Gal}-3^{-/}$mice that was accompanied by a significant decrease in epithelial cell damage, oedema, ulceration and destruction of crypts (Figure 1D, E). These findings are in line with our recently 
published data in which we showed that Gal-3 promotes activation of the NLRP3 inflammasome and production of IL-1 $\beta$ in colon-infiltrating macrophages (7) and that pharmacological inhibition of Gal-3 enhances the capacity of mesenchymal stromal cells to promote alternative activation of macrophages in DSS-induced colitis (28).

Several bacterial species were isolated from colons of UC patents, and some of them may modulate the activity of DSS, playing important roles in the induction of colitis $(29,30,31)$. An increased number of Escherichia coli species were isolated from colons of UC patients $(29,30)$. DSS is depolymerized in mouse faeces under aerobic conditions, and among all intestinal bacteria, Proteus mirabilis has the best ability to desulphonate and depolymerize DSS (32). In line with these findings, we noticed a significantly higher presence of Escherichia Coli and Proteus species in DSS-treated Gal-3 ${ }^{-1-}$ mice (Figure 3) that correlated with attenuated disease in these animals.

Since metronidazole alone or in combination with ciprofloxacin may attenuate chronic TNBS-induced colitis in rats (33) and carrageenan-induced colitis in guinea pigs (34), and since a combination of these antibiotics is effective against Gram negative bacteria such as Escherichia coli and Proteus, we used these antibiotics to determine the possible role of Gal-3 in the e interactions between intestinal microflora and the activity of phagocytic cells in acute colitis. We observed that the combination of metronidazole and ciprofloxacin significantly attenuated acute DSSinduced colitis in WT and Gal-3/- mice, as determined by clinical and histological scores (Figure 4). Nevertheless, the differences in clinical and histological scores between DSS-injured WT and Gal-3/- mice were still evident in the antibiotic treated animals, indicating that the Gal-3 dependent decrease in the presence of phagocytic cells in the inflamed colons was not directly related to the content of intestinal microflora.

\section{Acknowledgements}

This work was funded by Faculty of Medical Sciences University of Kragujevac, Serbia (Grant JP 2/09: "Immunomodulation of chronic inflammatory diseases").

\section{REFERENCES}

1. Bouma G, Strober W. The immunological and genetic basis of inflammatory bowel disease. Nat Rev Immunol. 2003; 3:521-533.

2. Mizoguchi A, Mizoguchi E. Inflammatory bowel disease, past, present and future: lessons from animal models. J Gastroenterol. 2008; 43:1-17.

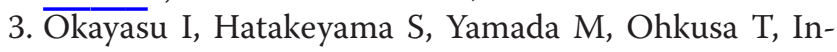
agaki Y, Nakaya R. A novel method in the induction of reliable experimental acute and chronic ulcerative colitis in mice. Gastroenterology. 1990; 98:694-702.
4. Perše M, Cerar A. Dextran sodium sulphate colitis mouse model: traps and tricks. J Biomed Biotechnol. 2012; 2012:718617.

5. Volarevic V, Milovanovic M, Ljujic B, et al. Galectin-3 Deficiency Prevents Concanavalin A- Induced Hepatitis in Mice. Hepatology 2012; 55:1954-1964.

6. Jiang H-R, Al Rasebi Z, Mensah-Brown E, et al. Galectin-3 Deficiency Reduces the Severity of Experimental Autoimmune Encephalomyelitis. J Immunol 2009; 182:1167-1173.

7. Simovic Markovic B, Nikolic A, Gazdic M, Bojic S, Vucicevic L, Kosic M, Mitrovic S, Milosavljevic M, Besra G, Trajkovic V, Arsenijevic N, Lukic ML, Volarevic V. Galectin-3 Plays an Important Proinflammatory Role in the Induction Phase of Acute Colitis by Promoting Activation of NLRP3 Inflammasome and Production of IL- $1 \beta$ in Macrophages. J Crohns Colitis. 2016; 10: 593-606.

8. Radosavljevic G, Jovanovic I, Majstorovic I, et al. Deletion of galectin-3 in the host attenuates metastasis of murine melanoma by modulating tumor adhesion and NK cell activity. Clin Exp Metastasis 2011; 28:451-462.

9. Radosavljevic G, Volarevic V, Jovanovic I, et al. The roles of Galectin-3 in autoimmunity and tumor progression. Immunol Res 2012; 52:100-110.

10. Arsenijevic A, Milovanovic M, Milovanovic J, Stojanovic B, Zdravkovic N, Leung PS, Liu FT, Gershwin ME, Lukic ML. Deletion of Galectin-3 Enhances Xenobiotic Induced Murine Primary Biliary Cholangitis by Facilitating Apoptosis of BECs and Release of Autoantigens. Sci Rep. 2016; 6:23348.

11. Pejnovic N, Pantic J, Jovanovic I, et al. Galectin-3 Deficiency Accelerates High-Fat Diet Induced Obesity and Amplifies Inflammation in Adipose Tissue and Pancreatic Islets. Diabetes 2013; 62:1932-1944.

12. Frol'ová L, Smetana K Jr, Borovská D, et al. Detection of galectin-3 in patients with inflammatory bowel diseases: new serum marker of active forms of IBD? Inflamm Res 2009; 58:503-512.

13. Müller S, Schaffer T, Flogerzi B, et al. Galectin-3 modulates $\mathrm{T}$ cell activity and is reduced in the inflamed intestinal epithelium in IBD. Inflamm Bowel Dis 2006; 12:588-597.

14. Brazowski E, Dotan I, Tulchinsky H, et al. Galectin-3 expression in pouchitis in patients with ulcerative colitis who underwent ileal pouch-anal anastomosis (IPAA). Pathol Res Pract 2009; 205:551-558.

15. Hsu DK, Yang RY, Pan Z, et al. Targeted disruption of the galectin-3 gene results in attenuated peritoneal inflammatory responses. Am J Pathol 2000; 156:1073-1083.

16. Murthy S, Cooper H, Shim H, et al. Treatment of dextran sulfate sodium-induced murine colitis by intracolonic cyclosporine. Dig Dis Sci 1993; 38:1722-1734.

17. Whittem CG, Williams AD, Williams CS. Murine Colitis Modeling using Dextran Sulfate Sodium. J Vis Exp 2010; 35:1652. 
18. Obermeier F, Kojouharoff G, Hans W, et al. Interferon-gamma (IFNgamma)- and tumour necrosis factor (TNF)-induced nitric oxide as toxic effector molecule in chronic dextran sulphate sodium (DSS)-induced colitis in mice. Clin Exp Immunol 1999; 116:238-245.

19. Hans W, Schölmerich J, Gross V, Falk W. The role of the resident intestinal flora in acute and chronic dextran sulfate sodium-induced colitis in mice. Eur J Gastroenterol Hepatol. 2000; 12:267-273.

20. Hall GS, Woods GL. Medical bacteriology. In: McPherson RA, Pincus MR, eds. Henry's Clinical Diagnosis and Management by Laboratory Methods. 23rd ed. Philadelphia, PA: Elsevier; 2017: chap 58.

21. Sadlack B, Merz H, Schorle H, Schimpl A, Feller AC, Horak I. Ulcerative colitis-like disease in mice with a disrupted interleukin-2 gene. Cell. 1993; 75:253-261.

22. Kühn R, Löhler J, Rennick D, Rajewsky K, Müller W. Interleukin-10-deficient mice develop chronic enterocolitis. Cell. 1993; 75:263-274.

23. Sellon RK, Tonkonogy S, Schultz M, Dieleman LA, Grenther W, Balish E, Rennick DM, Sartor RB. Resident enteric bacteria are necessary for development of spontaneous colitis and immune system activation in interleukin-10-deficient mice. Infect Immun. 1998; 66:5224-5231.

24. Gitter AH, Wullstein F, Fromm M, Schulzke JD. Epithelial barrier defects in ulcerative colitis: characterization and quantification by electrophysiological imaging. Gastroenterology 2001; 121:1320-1328.

25. Bodger K, Halfvarson J, Dodson AR, et al. Altered colonic glycoprotein expression in unaffected monozygotic twins of inflammatory bowel disease patients. Gut 2006; 55:973- 977.

26. Hsu DK, Chernyavsky AI, Chen HY, et al. Endogenous galectin-3 is localized in membrane lipid rafts and reg- ulates migration of dendritic cells. J Invest Dermatol 2009; 129:573-583.

27. Liu FT, Hsu DK. The role of galectin-3 in promotion of the inflammatory response. Drug News Perspect 2007; 20:455-460.

28. Simovic Markovic B, Nikolic A, Gazdic M, Nurkovic J, Djordjevic I, Arsenijevic N, Stojkovic M, Lukic ML, Volarevic V. Pharmacological Inhibition of Gal-3 in Mesenchymal Stem Cells Enhances Their Capacity to Promote Alternative Activation of Macrophages in Dextran Sulphate Sodium-Induced Colitis. Stem Cells Int. 2016; 2016:2640746.

29. Bodger K, Halfvarson J, Dodson AR, et al. Altered colonic glycoprotein expression in unaffected monozygotic twins of inflammatory bowel disease patients. Gut 2006; 55:973- 977.

30. Kotlowski R, Bernstein CN, Sepehri S, Krause DO. High prevalence of Escherichia coli belonging to the $\mathrm{B} 2+\mathrm{D}$ phylogenetic group in inflammatory bowel disease. Gut 2007; 56:669-675.

31. Walmsley RS, Anthony A, Sim R, Pounder RE, Wakefield AJ. Absence of Escherichia coli, Listeria monocytogenes, and Klebsiella pneumoniae antigens within inflammatory bowel disease tissues. J Clin Pathol. 1998; 51:657-661.

32. Araki Y, Mukaisho K, Sugihara H, Fujiyama Y, Hattori T. Proteus mirabilis sp. intestinal microflora grow in a dextran sulfate sodium-rich environment. Int J Mol Med. 2010; 25:203-208.

33. Videla S, Vilaseca J, Guarner F, Salas A, Treserra F, Crespo E, Antolín M, Malagelada JR. Role of intestinal microflora in chronic inflammation and ulceration of the rat colon. Gut. 1994; 35:1090-1097.

34. Onderdonk AB, Hermos JA, Dzink JL, Bartlett JG. Protective effect of metronidazole in experimental ulcerative colitis. Gastroenterology. 1978; 74:521-526. 